\title{
Examining the effect of an environmental social marketing intervention among university employees
}

\section{Diana Gregory-Smith*}

Birmingham Business School, University of Birmingham, Birmingham, UK

\section{Danae Manika}

School of Business and Management, Queen Mary University of London, London, UK

\author{
Victoria. K. Wells
}

Sheffield University Management School, University of Sheffield, Sheffield, UK

\section{Tom Veitch}

Global Action Plan, London, UK

* Corresponding author: Dr Diana Gregory-Smith, Birmingham Business School, University of Birmingham, University House, Edgbaston, Birmingham, B15 2TT; email: diana83ene@yahoo.com; telephone: $+44(0) 1214143344$ 


\title{
Examining the effect of an environmental social marketing intervention among university employees
}

\begin{abstract}
This paper examines the impact of an environmental social marketing intervention on employees' energy saving intentions in a higher education institution (HEI) in the UK. The study examines the influence of both individual (attitudes, knowledge, norms) and organisational (perceived organisational behaviour, perceived organisational support) variables on intentions to save energy in the workplace. A quantitative methodology was used in the form of a survey, which also included open-ended survey questions. The quantitative data highlighted the important role of both general and specific attitudes in determining intentions. Additionally, data from the open-ended questions highlighted the importance of organisational behaviour, particularly support, policies and barrier reduction strategies in determining employees' pro-environmental intentions and behaviour. Differences were noted between employees in terms of their job roles (academic vs. non-academic) and the job duration. In the light of the findings, implications for sustainability in HEIs are discussed along with directions for future research.
\end{abstract}

Keywords: social marketing; higher education institution; sustainability; energy; employees; pro-environmental behaviour.

\section{Introduction}

Recent years have seen an increasing interest in higher education institutions' (HEIs) sustainability, both in terms of the curriculum and the operations of these institutions (Fien 2002). In addition, HEIs are expected to take the lead in action to mitigate environmental problems (Brennan, Binney, and Hall 2015). The limited studies in this area have focused on three aspects, (1) education for sustainability/sustainability education (e.g. Shephard and Furnari 2013; Swain et al. 2014), (2) environmental behaviours of students (Emanuel and Adams 2011; Butt, More and Avery 2014) and (3) campus-wide initiatives (capturing the behaviours of staff, and sometimes students (e.g. Levy and Marans 2012)). 
Studies focusing on HEIs have examined barriers to pro-environmental behaviour (PEB) (Aronof et al. 2013), concerns and awareness of campus sustainability (Soares et al. 2015), individual variables such as subjective norms, perceived behavioural control, sense of community and attitudes (Dixon et al. 2015a; 2015b) and different feedback, campaign and communications techniques (Cole and Fieselman 2013; Dixon et al. 2015a). Additionally, studies by Marans and colleagues have also sought to understand broad campus initiatives focused on both staff and students and to provide an understanding of energy behaviour in the workplace and willingness to change behaviour, as well as the development of strategies such as leadership, monitoring and education to encourage PEB (Marans and Edelstein 2010; Levy and Marans 2012). However, one approach that has been popular in the wider employee PEB literature is social marketing (Gregory-Smith et al. 2015), but this has not been used considerably in the HEI context and its full potential has not been tested in this context. While some recent attempts have been made to use social marketing techniques on students in a hall of residence (Parece et al. 2013), the use of social marketing for behaviour change in the HEI context is very limited.

Therefore, the present study adds to this limited literature by studying the effects of a social marketing campaign ${ }^{1}$ to reduce energy use of staff in a university in the UK. While various variables have been utilised to study employee PEB, there is increasing understanding that both individual and organisational variables are important in determining employees' level of sustainable behaviour and their reactions to interventions (Manika et al. 2015). Additionally, Manika et al. (2015) highlight that 'one size does not fit all' and each type of organisation needs to be assessed individually before designing an environmental intervention; this is because what may work in one type of organisation may not apply elsewhere. Employee pro-environmental studies in HEIs have not yet examined both

\footnotetext{
${ }^{1}$ In this paper the terms social marketing campaign and social marketing intervention are used interchangeably.
} 
organisational and individual variables extensively, nor tested them through an intervention. This paper covers these gaps in the literature.

\section{Literature review}

\section{General environmentally friendly attitudes}

Attitudes, often characterised as environmental concern, are regarded as a key antecedent of environmental behaviour and recent evidence suggests environmental attitudes, at least in the home, are associated with lower energy consumption, (Sapci and Considine 2014). In workplace based studies, results are mixed but, generally, attitudes are considered to be a key predictor of employees' PEB (Marans and Lee 1993; Tudor, Barr, and Gilg 2008). Some studies suggest a weaker relationship between environmental concern and behaviour (Schultz, Oskamp \& Maineri, 1995) but this has generally been considered to be because the level of specificity of the behaviour and attitudes is not the same, an issue which will be discussed further below. Attitudes are often used as part of a Theory of Planned Behaviour approach to PEB, and have been the basis for a number of university-situated studies (Dixon et al. 2015a; 2015b), where they have been shown to predict behavioural intentions and are considered strong predictors of energy conservation intentions.

\section{Energy saving attitudes}

Specific attitudes, i.e. specific to the target behaviour, have often been found to be more predictive of both behaviour and behavioural intentions than general attitudes because they are at the same level of specificity (Vinning and Ebreo 2002) overcoming the mixed results attributed to more general attitudes. A number of studies examining employee PEB, have used specific attitudes towards the behaviour (Lee et al., 1995; Siero et al., 1996) and found them to be predictive of behaviour. Few studies have examined both the effects of general and specific attitudes and, as Polonsky et al (2012) note in their study of general and carbon- 
related environmental knowledge on general environmental attitudes, future research should explore both specific and general attitudes. In addition, research also suggests general environmental attitudes play a part in the development of more specific attitudes (Manika et al. 2014). Thus:

H1: General environmentally friendly attitudes will have a positive and significant relationship with energy saving attitudes.

\section{Perceived energy saving knowledge}

While attitudes are commonly studied in the PEB literature they are not the only variable that is considered important in the development and encouragement of PEB in the workplace. Knowledge is also highlighted as a necessary condition (although not sufficient on its own (Ones and Dilchert (2012)) for individuals to engage in PEBs (Lo, Peters, and Kok 2012) and may affect the internalisation of environmental management practices by employees (Boiral, Paillé \& Raineri, 2015) and environmental performance (Ones and Dilchert, 2013). Different types of knowledge such as practical knowledge of recycling materials, disposal processes etc and procedural knowledge such as an awareness of environmental issues or policies have been deemed important in determining employee PEB (Coleman at al, 2013; Young et al, 2015). A number of studies have broadly highlighted the importance of knowledge for employees in a number of contexts (Siero et al. 1996; Tudor, Barr, and Gilg 2008), but in the university context this has only been partial explored (Marans and Edelstein 2010) with the suggestion that both knowledge of issues and procedures are important for influencing PEBs (Levy and Marans, 2012).

Additionally, the use of education, to increase knowledge, has also been highlighted as an important way to develop and support pro-environmental behaviours within universities (Levy and Marans, 2012). Brennan, Binney and Hall (2015) highlight that without knowledge of the relevant environmental processes/procedures, individuals will not be 
persuaded to engage with environmental behaviour in the workplace and Tonglet, Phillips and Read (2004) consider knowledge influences environmental engagement, attitudes and behaviour. In addition, Aronof et al (2013) suggest that educating individuals could increase their knowledge and in turn their awareness of environmental issues and Soares et al (2015) note that raising awareness is a priority for increasing energy efficiency in higher education buildings. Indeed, Unsworth et al (2013) suggest for employee PEB interventions to engage employees they should both increase knowledge and seek to change attitudes. Thus:

H2: Perceived energy saving knowledge at the workplace will have positive and significant relationship with energy saving attitudes.

\section{Workplace energy saving behavioural intentions}

Both Vinning and Ebreo (2002), and Steg and Vlek (2009) highlight the multiple behavioural focuses that have been utilised in general and employee environmental behaviour research. Past studies have focused mainly on employees' recycling/waste management behaviour, (Ludwig et al., 1998; Marans \& Lee 1993; McDonald, 2011; Tudor et al., 2008), but studies have also researched climate control, lights, (Lo et al., 2012a; 2012b), driving behaviour (Siero et al., 1989), computers, lights and fan usage (Scherbaum et al., 2008) and energy use (Carrico \& Riemer, 2011) amongst others. Studies in HEIs have focused in particular on energy conservation (Aronof et al. 2013; Dixon et al. 2015a; 2015b) and the present paper continues this focus. The particular focus here is also on behavioural intention, which as noted previously aligns with a Theory of Planned Behaviour approach to PEB, and subsequently has been the basis for a number of university-situated studies (Dixon et al. 2015a; 2015b). This paper continues this tradition, allowing for easier comparison across HEI focused employee PEB studies. In addition, the attitude - behavioural intention link is well established (Dixon et al. 2015) and knowledge has also been shown to effect environmental behavioural intentions (Tonglet, Phillips, and Read 2004 - measured as part of Perceived Control). Thus: 
H3: Energy saving attitudes will have positive and significant relationship with workplace energy saving behavioural intentions.

H4: Perceived energy saving knowledge at the workplace will have positive and significant relationship with workplace energy saving behavioural intentions.

\section{Subjective norms}

We are expected to conform to the actions and beliefs of those around us, that is our peers (Aronof et al, 2013) and hence to fall in line with social norms demonstrating what is termed a normative influence. Carrico and Riemer (2011) suggest behaviour is more easily observed by one's peers in the workplace relative to the home and, therefore, employees may be more vulnerable to these processes of normative influence e.g. an individual feels pressure from one's peers to conserve energy. The use of Value-Belief-Norm theory (Scherbaum, Popovich, and Finlinson 2008) highlights the role of norms in PEB and while a number of employee PEB studies disagree over the influence of norms on behavioural intentions (Scherbaum, Popovich, and Finlinson 2008) there is a suggestion that norms do have a significant effect on employee PEBs (Lamm, Tosti-Kharas and Williams, 2013). This is also the case in the university context where it is suggested norms are positively related to behavioural intentions to perform workplace energy conservation (Dixon et al. 2015b). As environmental norms are related to what is normal in the workplace they are also likely to be affected by how environmental employees perceive their organisation to be acting; although this does not appear to have been tested previously. Starik and Rands $(1995,918)$ consider ecologically sustainable organisations "promote the value of environmental protection and sustainable organisational performance, [and] instil norms for environmental sensitivity in all decisions', while the organisational citizenship literature considers that employees' prosocial norms and behaviour can be influenced by organisational behaviour, represented specifically by leaders who act as role-models (Smith, Organ, and Near, 1983). Thus: 
H5: Perceived organisational behaviour will have positive and significant relationship with subjective norms.

H6: Subjective norms will have positive and significant relationship with workplace energy saving behavioural intentions.

\section{Perceived organisational behaviour}

Hansen et al. (2011) and Rupp et al. (2006) note that employees respond positively to the CSR activities of their employers (i.e., their perceptions of the organization's environmental reputation and behavior) and, specifically, that employees who perceive their employer as more socially responsible are more likely to engage in organisational citizenship behaviours (OCBs) and PEB has been conceptualized as a type of OCB (Lamm, Tosti-Kharas, and Williams 2013). Conversely, if organizations do not behave in a socially responsible way, employees are likely to exhibit negative work attitudes and behaviours (Rupp et al., 2006; Hansen et al., 2011). Prior research suggests an organisation's PEB behaviour affects employees' behaviour and attitudes in a number of ways. Firstly, the organisation's commitment to PEBs is important especially where the employee feels there is good personorganisation fit between the environmental values of the organisation and the employee which can lead to employee-company identification (Kim et al., 2010). Additionally, Andersson et al. (2005) note that when supervisors perceive that their company is committed to environmental sustainability they, in turn, are more likely to demonstrate pro-environmental behaviours and to also direct these towards the employees they supervise. Secondly the focus or structure of the organisation, and how it facilitates individual employees' decision making may in turn affect an individual's motivations and behaviour (Tudor, Barr, and Gilg 2008). In particular, Ramus and Steger (2000) and Andersson, Shivarajan, and Blau (2005) found that the perception of a company's environmental policy (representing commitment to the environment) helps determine employees' intention to partake in PEB. Thus: 
H7: Perceived organisational behaviour will have positive and significant relationship with workplace energy saving behavioural intentions.

\section{Perceived organisational support}

Perceived organisational support (POS), the 'general belief that their work organisation values their contribution and cares about their well-being' and its link to in role-performance and extra role behaviours is well established in the literature (Rhoades and Eisenberger 2002, 698). POS is believed to result in greater organisational commitment, job involvement, positive mood and to reduce job strain (Rhoades and Eisenberger 2002). The employee PEB literature also highlights the role of POS in determining the level and type of employee PEB (Ramus and Steger 2000; Smith and O'Sullivan 2012). Where employees perceived strong signals of support and encouragement from the organisation they were more likely to develop and implement eco-behaviours (Ramus and Steger (2000). Thus, high levels of perceived organisational support are likely to result in greater PEB and intentions in the workplace and a view of the organisation as being environmentally friendly as organisational support, especially support for PEBs, will be taken into account by employees in determining their perception of the organisations environmental behaviours. Moreover, Ramus and Steger (2000) found employees who perceived strong signals of support from the organisation, were more likely to develop and implement eco-behaviours. To summarise, POS forms a part of the perceived overall environmental behaviour of the firm (Ramus and Steger 2000) and, thus, is likely to have a positive effect on employees' perceptions of the organisation's overall environmental behaviour. Thus:

H8: Perceived organisational support will have positive and significant relationship with perceived organisational behaviour.

H9: Perceived organisational support will have positive and significant relationship with workplace energy saving behavioural intentions. 
Additionally, to the authors' knowledge, neither Perceived Organisational Behaviour nor POS have been previously examined in the university employee PEB context, where the focus has largely been on individual variables. Hence, this paper extends the current literature. The hypothesised relationships are illustrated in Figure 1.

[Figure 1 near here]

\section{Methodology}

The data from this study were collected by environmental charity Global Action Plan (GAP) who implemented an energy saving intervention ('Go Green') focused on the employees of a British university. The intervention recruited and trained a network of green champions to take the sustainability message to their workplaces i.e. motivate energy saving actions among university employees. A dedicated intranet site was created so that green champions could share best practice and employees could make pledges to switch off lights, computer/screens etc. 1,351 employees took at least one pledge related to energy saving.

To evaluate the success of the intervention a quantitative methodology was used, with pre and post-intervention questionnaires. The questionnaires measured individual and organisational variables (as detailed above) and employees' energy saving intentions, along with a series of open-ended questions to gain a more in-depth perspective. Anonymity was ensured to encourage participation and to minimise social desirability bias. Therefore, the employees who filled out the pre and post-intervention questionnaires might have been different given the anonymity of the data collection.

A total sample of 368 questionnaires were completed and comprised two balanced samples $(\mathrm{n}$ pre-intervention $=164 ; \mathrm{n}$ post-intervention $=164)$. Each questionnaire consisted of 26 items measured on 1-5 and 1-7 Likert scales and demographics were measured with multiple-choice questions (Table 1).

[Table 1 near here] 
Energy saving attitudes, General environmental attitudes, and Perceived organisational behaviour were multi-item scales and all others were single-item scales. The questionnaire was not originally designed for the purpose of testing the aforementioned hypotheses and, thus, validated academic scales were not used to measure the constructs. Therefore, this study should be treated as exploratory. Nevertheless, the use of real data reduces the artificiality, lack of realism and generalizability associated with laboratory studies (see Peterson and Merunka 2014). Furthermore, single-item measures are increasingly accepted as adequate alternatives when designed appropriately (Fuchs and Diamantopoulos 2009; Hoeppner, Urbanoski, and Slaymaker 2011). The measurement of the dependent variable, behavioural intentions, as a single-item is also considered acceptable as this construct is unlikely to have different meanings for different people (Fuchs and Diamantopoulos 2009).

Exploratory factor analysis was conducted and Cronbach's alphas were computed for the pre and post-intervention data and the combined sample, for each multi-item scale (see Table 1). Reliability and validity were established. There was also an adequate variable-tosample ratio for both pre and post-intervention datasets, and no signs of extreme multicollinearity were found (Hair et al. 1998). Descriptive statistics and correlations were computed for all variables, for both the pre and post-intervention datasets (by calculating the composite scores of the multi-items constructs) (Table 2). None of the inter-correlations among the constructs were greater than 0.85 signifying discriminant validity.

\section{[Table 2 near here]}

For both the pre and post-intervention datasets, most participants were female $\left(\mathrm{n}_{\text {pre }}=107 ; \mathrm{n}_{\text {post }}=124\right)$. One third of the participants in both datasets were 31 to 40 years old, while in the combined sample age ranged from 18 to 70 . In both datasets there was about one third for each job duration group. In terms of job type, the data sets were comparable across managers (non-academic) $\left(\mathrm{n}_{\text {pre }}=82 ; \mathrm{n}_{\text {post }}=75\right)$ support staff $\left(\mathrm{n}_{\text {pre }}=65 ; \mathrm{n}_{\text {post }}=63\right)$, academics 
$\left(\mathrm{n}_{\text {pre }}=13 ; \mathrm{n}_{\text {post }}=23\right)$ and research staff $\left(\mathrm{n}_{\mathrm{pre}}=4 ; \mathrm{n}_{\text {post }}=1\right)$. The post dataset also included 2 full time teaching staff. No significant differences were found between the pre- and postintervention datasets in terms of job duration $(F(1,323)=3.366, p=.067)$ and job type $(\mathrm{F}(1,326)=.055, \mathrm{p}=.815)$. Thus, these datasets are comparable for the purpose of testing the proposed hypotheses. Differences between job types and job duration in terms of the main constructs of this study are also explored in a post-hoc analyses.

\section{Results}

\section{Structural equation modelling results and group differences}

Aligned with recent approaches (e.g. Manika et al. 2015), the hypotheses were examined using a conservative statistical approach (using observed variables rather than their latent versions) in combination with a structural equation modelling (SEM) technique using MPlus7.

Two separate SEM models were run for each dataset (pre and post-intervention samples). They revealed a good model fit for the pre-intervention dataset $\left(\chi_{(11)}^{2}=21.23, p=.03\right.$; $\left.\mathrm{CFI}=.97 ; \mathrm{TLI}=.95 ; \mathrm{SRMR}=.07 ; \mathrm{R}^{2}=60 \% ; \mathrm{n}=159\right)$ and an acceptable model fit for the postintervention dataset $\left(\chi_{(11)}^{2}=37.77, \mathrm{p}=.00 ; \mathrm{CFI}=.91 ; \mathrm{TLI}=.84 ; \mathrm{SRMR}=.09 ; \mathrm{R}^{2}=51.5 \%, \mathrm{n}=160\right)$. A multi-group SEM model was computed on the combined datasets, with the grouping variable as the exposure/non-exposure to the energy saving intervention. The overall model fit of the multi-group SEM was acceptable $\left(\chi^{2}(22)=59.00, \mathrm{p}=.00 ; \mathrm{CFI}=.94 ; \mathrm{TLI}=.90 ; \mathrm{SRMR}=.08\right)$ and indicated that the pre-intervention dataset has a better model fit than the post-intervention dataset (Table 3). The pre-intervention dataset model also accounted for a greater variance in behavioural intentions to save energy at the workplace $\left(\mathrm{R}^{2}=60 \%\right)$ than the post- intervention dataset model $\left(\mathrm{R}^{2}=51.5 \%\right)$.

[Table 3 near here] 
The chi-square value of this multi-group SEM, was then compared with the chi-square value of an SEM model were all paths were constrained to be equal across the two groups. The chi-square difference was significant $\left(\Delta \chi^{2}=225.96-59.00=166.96, \Delta \mathrm{df}=31-22=9, \mathrm{p}<.01\right)$ and the chi-square value of the non-constrained model was lower, and thus works better, than the constrained one. This finding, in combination with the fact that significant differences between the pre and post-intervention datasets exist in terms of model fit, indicate the two datasets (i.e. pre- and post-intervention) need to be examined separately.

Hypotheses 1, 2, 3 and 5 were supported in both the pre and post-intervention datasets. Hypothesis 7 was only supported for the pre-intervention dataset. Hypothesis 8 was only supported for the post-intervention dataset, although was significant in the opposite direction for the pre-intervention dataset. Hypotheses 4, 6 and 9 were not supported. Additional analyses were conducted to compare differences between the two datasets in terms of the main constructs. T-tests revealed the energy saving intervention resulted in significant increases in perceived organisational support, employees' subjective norms, and perceived energy saving knowledge (Table 3).

We also examined the effect of the intervention (via t-tests), across job types ${ }^{2}$ (Table 4). For managers (non-academic staff), POS and employee subjective norms increased significantly from the pre to the post-intervention period. For support staff, POS and perceived energy saving knowledge increased significantly from the pre to the postintervention datasets; however general environmental attitudes decreased significantly. For academics no observed changes were found.

\section{[Table 4 near here]}

T-tests were also computed for three job duration groups: less than 5 years, 5 to 10 years, and more than 10 years. Perceived organisational behaviour and POS increased

\footnotetext{
${ }^{2}$ Teaching only and Research only staff were excluded from this post-hoc analysis due to the minimal sample. size. Here the analysis compared only between managers, support staff and academics.
} 
significantly from the pre to the post-intervention dataset for employees in the less than 10 years group. POS also increased from the pre to the post-intervention for the 5 to 10 years and more than 10 years groups. For those employees who had worked at the university for more than 10 years, employee subjective norms and perceived energy saving knowledge also increased significantly from the pre to the post-intervention datasets.

[Table 5 near here]

\section{Open-ended survey questions results}

Two key themes emerged from both the pre- and post-intervention open-ended survey questions: (1) support and organisational behaviour (current and future) and (2) barriers to employee PEB.

Firstly, the organisations' environmental behaviour and the level and type of support from the organisation featured frequently in the both pre and post-intervention answers. Employees perceived a lack of coherent or clear policy/initiatives, and the intervention itself did not change these perceptions:

\footnotetext{
'Some initiatives have sounded a bit weird - like the coffee 'ecocup' survey a while back when we can be even greener and just use our normal coffee cups to buy coffee...' (preintervention)

'I am not aware of any environmental policies.' (post-intervention)
}

One particular policy of 'home working' was supported by the employees but not by the organisation and, therefore, many perceived the organisation was not doing all it could, to be sustainable:

'I could work from home....rather than travel to work every day (35 litres of fuel/week no public transport as live in village) but [this] will not be entertained.' (postintervention) 
Additionally, both pre-and post-intervention, the employees suggested the organisation did not listen to feedback from staff regarding environmental behaviours. This may explain why some of the hypotheses related to support and organisational behaviours were not supported.

'I don't know if the university listens to feedback from staff about environmental issues.' (pre-intervention)

'[We] have never been asked for feedback on environmental issues and have never seen a coherent environmental policy.' (post-intervention)

Secondly, a number of barriers to PEB were highlighted both in the pre- and postintervention data. Many of these barriers were technological or IT related, which led to lack of individual control:

'There are sometimes conflicts in our department between IT's requests to leave Linux machines on at all times to allow updating, automatic backups etc. and individuals' desires to turn them off to save energy.' (pre-intervention)

'I work in an open plan office so have no control over the heating nor any say in whether windows are open or closed.' (post-intervention)

'My biggest bugbear is that I am unable to turn off my PC at night because I regularly need to access my emails and other systems from home. If you turn your work PC off you are unable to do this.' (post-intervention)

Additionally, the need to consider these barriers at the organisational level were noted by employees:

'Many of the Go Green campaign initiatives seem trivial and pointless. IT \& Estates need to change their policies to make any serious difference. Lights are on permanently in my workplace because there isn't enough natural light. If you want PCs \& printers switched off overnight then put them all on time switches.' (post-intervention)

Pre-intervention, the employees also highlighted that their colleagues' habits are a barrier for sustainable behaviour in the workplace:

'More lights could be turned off in the evenings and over the weekend. Sometimes in the winter, I come in on a Monday morning and find (manual) lights on, and suspect they've been on all weekend. Printers in resource rooms should be turned off in the evenings/at weekends.'(pre-intervention) 
And while these barriers were mentioned in the post-intervention too, the frequency of these mentions had reduced (especially with regards to computers/lights).

Finally, respondents were willing and able to provide suggestions for both future campaigns (including a critique of the 'Go Green' campaign) and suggested policies/procedures both pre and post-intervention. These included: support from heads of units/managers (suggesting this had not improved noticeably because of the intervention); designation of green leaders who can oversee green behaviour uptake; workshops/training for employees; support for remote working and using internal knowledge/resource better:

'Any environmental initiatives should be wholly supported by heads of units.'(preintervention)

'We have [student] modules such as 'Sustainability at Work' to help individuals work more sustainably, but as far as I'm aware we don't have workshops/ training to encourage colleagues to go green.' (pre-intervention)

'I think the campaign is doing its best but I'm afraid it has not changed my behaviour as much as it could have done, but I don't know how it could do better - maybe posters with less, bigger text around the place saying TURN OFF, RECYCLE etc.' (postintervention)

\section{Discussion}

This study assessed the effects of a social marketing campaign, aiming to reduce energy use in a British university, by examining the role of both individual and organisational variables before and after the intervention. As predicted, the links between the individual variables of attitudes (both general and specific) and intentions were supported and although knowledge did impact on attitudes, neither attitudes nor norms affected intentions directly. The only organisational variable that affected intentions was perceived organisational behaviour (which in turn influenced norms) and this applied only in the pre-intervention survey. The openended survey responses showed a perceived lack of support both pre and post-intervention. They also indicated that the employees perceived the organisation was not as sustainable as it 
could be and did not listen to feedback, which could explain why some of the organisational hypotheses were not supported. However, the comparisons show that perceived organisational behaviour and POS did increase as a result of the intervention but that POS increased significantly for non-academic managers and support staff.

The open-ended survey responses also highlighted a number of technological and IT related barriers. These were similar to the structural barriers highlighted by Aronof et al. (2013), thus supporting prior literature. However, these issues had not been taken into account before the campaign and, hence, may also have added to the lack of a relationship between the organisational variables and behavioural intentions.

Workplace energy saving behaviour intentions did not increase significantly as a result of the campaign and this again could be the result of a lack of focus on organisational elements.

\section{Implications for sustainability in higher education}

This paper highlights a number of issues that need to be considered by mangers in HEIs who wish to improve the PEB of their employees. It is clear, from the open-ended survey responses that support and perceived organisational behaviour are important and, in many ways, must be a precursor for any campaign focused on PEB in the workplace. The HEI must demonstrate its support for environmental policies and show itself to be making sustainable decisions before asking individuals to change their behaviour. Alongside this, a barrier reduction strategy must also be developed prior to any campaign. This aligns well with Brennan, Binney, and Hall's (2015) 9P's framework that highlights the need for the behavioural infrastructure to be appropriate before individuals can be expected to change their behaviour and clear policies, processes and procedures need to be in place and promoted before individuals can fully engage in PEB and change their behaviour. Based on the present results, it becomes clear that HEIs have to commit to these interventions as much as the 
employees, not only for credibility reasons but also to ensure the success of any peoplefocused intervention. The actions of the green leaders were valued by the university employees, but future interventions need to involve more middle and upper-level management. In doing so, they would demonstrate that the organisation's environmental concern, as depicted in the curriculum, is also reflected in the practices managers encourage within the university and their own individual behaviour/practices.

\section{Limitations and future research}

Some limitations should be highlighted, along with future research directions. Firstly, while self-reported behaviour measures (pre and post-interventions) are an adequate indicator of behaviour change, actual behaviour change measures (for example observations or energy data) are important for assessing the success of the intervention and should be collected in future studies.

Further research should build on the highlighted differences between different job roles (academic versus non-academic) and job duration, which should be examined in more depth (e.g. via a qualitative study). This might mean that different campaigns or social marketing techniques should be used for each group. Future research should seek additional clarifications about these differences before this can be implemented.

It is clear from the open-ended survey responses that further engagement of all employees is of high importance, especially where employees have potential suggestions for improvement but feel their views are not being listened. One way to do this and to develop future campaigns, is through the use of Community Based Social Marketing (CBSM). This is an alternative to information-intensive campaigns and focuses on barriers to and benefits of behaviour change, particularly via community level initiatives (Kennedy 2010; McKenzieMohr 2011). CBSM has also been highlighted as a practical and educational approach 
appropriate for HEIs (Cole and Fieselman 2013). Another approach is to use internal social marketing in order to align activities with the goals of sustainability, to foster internal communication and social networks and to manage expectation and outcomes (Brennan, Binney, and Hall 2015).

\section{Concluding comments}

This paper sought to extend the academic literature on sustainability in HEIs by assessing the role of both individual and organisational variables on employees' intentions to save energy in the workplace. While the SEM results showed that individual variables are important in determining behavioural intentions, the open-ended responses showed the importance of organisational elements and aspects that require consideration before a campaign commences, such as barrier reduction and demonstration of HEI sustainability policies and procedures. 


\section{References}

Aguinis, H. and A. Glavas. 2012. "What We Know and Don't Know About Corporate Social Responsibility: A Review and Research Agenda.” Journal of Management 38 (4): 932968.

Andersson, L., S. Shivarajan, and G. Blau. 2005. “Enacting Ecological Sustainability in the MNC: A test of an Adapted Value-Belief-Norm Framework." Journal of Business Ethics 59 (3): 295-305.

Aronoff, J., B. Champion, C. Lauer, and A. Pahwa. 2013. "Teaching Old Dogs New Tricks: The Effectiveness of Community-based Social Marketing on Energy Conservation for Sustainable University Campuses." IEEE Power and Energy Magazine 11 (1): 30-38.

Borial, O., Paillé, P., \& Raineri, N. 2015. "The Nature of Employees' ProEnvironmental Behaviors.” In: Robertson, J.L \& Barling, J (eds) The Psychology of Green Organisations, Oxford University Press, pp 12-32

Brennan, L., W. Binney, and J. Hall. 2015. “Internal Social Marketing, Servicescapes and Sustainability: A Behavioural Infrastructure Approach”. In: W.Wymer (eds) Innovations in Social Marketing and Public Health Communication: Improving the Quality of Life for Individuals and Communities: 87-105

Butt, L., E. More, and G. C. Avery. 2014. “The Myth of the 'Green Student': Student Involvement in Australian University Sustainability Programmes." Studies in Higher Education 39 (5): 786-804.

Carrico, A. R., and M. Riemer. 2011. "Motivating Energy Conservation in the Workplace: An Evaluation of the Use of Group-level Feedback and Peer Education.” Journal of Environmental Psychology 31 (1): 1-13. 
Cole, E. J., and L. Fieselman. 2013. "A Community-based Social Marketing Campaign at Pacific University Oregon.” International Journal of Sustainability in Higher Education 14 (2): 176-195.

Coleman, M.J, Irvine, K.N, Lemon, M and Shao, L. 2013. "Promoting behaviour change through personalized energy feedback in offices." Building Research \& Innovation, 41(6), 637-651. Doi: 10.1080/09613218.2013.808958

Dixon, G. N., M. B. Deline, K. McComas, L. Chambliss, L., and M. Hoffmann. 2015a. "Using Comparative Feedback to Influence Workplace Energy Conservation: A Case Study of a University Campaign.” Environment and Behavior 47 (6): 667-693.

Dixon, G. N, M. B. Deline, K. McComas, L. Chambliss, and M. Hoffmann. 2015b. "Saving Energy at the Workplace: The Salience of Behavioral Antecedents and Sense of Community." Energy Research and Social Science 6: 121-127.

Emanuel, R., and J. N. Adams. 2011. “College Students' Perceptions of Campus Sustainability." International Journal of Sustainability in Higher Education 12 (1): 79-92.

Fien, J. 2002. "Advancing Sustainability in Higher Education: Issues and Opportunities for Research.” Higher Education Policy 15 (2): 143-152.

Fuchs, C., and A. Diamantopoulos. 2009. "Using Single-item Measures for Construct Measurement in Management Research.” Die Betriebswirtschaft 69 (2): 195-210.

Gregory-Smith, D., V. K. Wells, D. Manika, and S. Graham. 2015. “An Environmental Social Marketing Intervention among Employees: Assessing Attitude and Behaviour Change.” Journal of Marketing Management 31 (3-4): 336-377.

Hair, J. F. Jr., R. E. Anderson, R. L. Tatham, and W. C. Black (1998). Multivariate Data Analysis. Englewood Cliffs, NJ: Prentice Hall. 
Hansen, S. D., B. B. Dunford, A. D. Boss, R. W. Boss, and I. Angermeier. 2011. Corporate Social Responsibility and the Benefits of Employee Trust: A Cross-disciplinary Perspective.” Journal of Business Ethics 102 (1): 29-45.

Hoeppner, B. B., J. F. Kelly, K. A. Urbanoski, and V. Slaymaker. 2011. Comparative Utility of a Single-item versus Multiple-item Measure of Self-efficacy in Predicting Relapse among Young Adults.” Journal of Substance Abuse Treatment 41 (3): 305-312.

Kennedy, A. L. 2010. "Using Community-Based Social Marketing Techniques to Enhance Environmental Regulation.” Sustainability 2: 1138-1160.

Kim, H-R., Lee, M., Lee, H-T. and Kim, N-M. 2010. “Corporate social responsibility and employee-company identification." Journal of Business Ethics, 95, 557-569. doi: $10.1007 / \mathrm{s} 10551-010-0440-2$

Lamm, E., J. Tosti-Kharas, and E. G. Williams, E. G. 2013. "Read This Article, But Don't Print It: Organizational Citizenship Behavior toward the Environment." Group \& Organization Management 38 (2): 163-197. doi:10.1177/1059601112475210

Levy, B. L. M., and R. W. Marans, R.W. 2012. "Towards a Campus Culture of Environmental Sustainability: Recommendations for a Large University." International Journal of Sustainability in Higher Education 13 (4): 365-377. doi: $10.1108 / 14676371211262317$

Lo, S-H., G-J., Y. Peters, and G. Kok. 2012. "Energy-Related behaviors in Office Buildings: A Qualitative Study on Individual and Organisational Determinants.” Applied Psychology: An International Review 62 (2): 227-249.

Manika, D., D. Gregory-Smith., V. K. Wells, and S. Graham. 2014. "Cognitive, Attitudinal and Behavioral Variables as Predictors of Energy Saving Behavior among Employees.” European Marketing Association Conference (EMAC), Valencia, 3rd-6th June 2014. 
Manika, D., V. K. Wells, D. Gregory-Smith, and M. Gentry. 2015. "The Impact of Individual Attitudinal and Organisational Variables on Workplace Environmentally Friendly Behaviours.” Journal of Business Ethics 126 (4): 663-684. doi: 10.1007/s10551-013-1978-6

Marans, R. W., and J. Y. Edelstein. 2010. “The Human Dimension of Energy Conservation and Sustainability: A Case Study of the University of Michigan's Energy Conservation Program." International Journal of Sustainability in Higher Education 11(1): 618.

McKenzie-Mohr, D. 2011. Fostering Sustainable Behavior: An Introduction to Community-based Social Marketing. New Society Publishers, Third Edition.

Ones, D.S., and Dilchert, S. 2012. "Employee Green Behaviors.” In: Jackson., S.E, Ones, D and Dilchert, S. (eds) Managing human resources for environmental sustainability, San Francisco: Jossey-Bass, pp 85-116

Ones, D.S and Dilchert, S. 2013. "Measuring, Undersanding, and Influencing Employee Green Behaviors.” In: A.H.Huffman \& S.R.Klein (eds) Green organizations: Driving change with I-O psychology. (pp 115-148) New York: Routledge.

Parece, T. E., T. Younos, L. S. Grossman, and E. S. Geller. 2013. "A Study of Environmentally Relevant Behavior in University Residence Halls.” International Journal of Sustainability in Higher Education 14 (4): 466-481.

Peterson, R. A., and Merunka, D. R. 2014. “Convenience Samples of College Students and Research Reproducibility. Journal of Business Research 67(5): 1035-1041.

Polonsky, M.J., Vocine, A., Landreth, S., Garma, R., \& Ferdous, A.S. 2012. "The impact of general and carbon-related environmental knowledge on attitudes and behaviour of US consumers." Journal of Marketing Management, 28(3-4), 238-263. doi: http://dx.doi.org/10.1080/0267257X.2012.659279 
Ramus, C. A. and U. Steger. 2000. "The Roles of Supervisory Support Behaviors and Environmental Policy in Employee "Ecoinitiatives" at Leading-edge European Companies." Academy of Management Journal 43 (4): 605-626.

Rhoades, L., and R. Eisenberger. 2002. "Perceived Organizational Support: A Review of the Literature.” Journal of Applied Psychology 87 (4): 698-714.

Sapci, O., and T. Considine. 2014. "The Link Between Environmental Attitudes and Energy Consumption Behavior.” Journal of Behavioral and Experimental Economics 52: 2934.

Scherbaum, C., P. M. Popovich, and S. Finlinson. 2008. "Exploring Individual-Level factors Related to Employee Energy-Conservation Behaviors at Work." Journal of Applied Social Psychology 36 (3): 818-835.

Shephard, K., and M. Furnari. 2013. "Exploring What University Teachers Think about Education for Sustainability.” Studies in Higher Education, 38 (10): 1577-1590.

Siero, F. W., A. R. Bakker, G. B. Dekker, M. T. C. van den Burg. 1996. “Changing Organizational Energy Consumption Behaviour through Comparative Feedback." Journal of Environmental Psychology 16: 235-246.

Smith, A. M., and T. O’Sullivan. 2012. "Environmentally Responsible Behaviour in the Workplace: An Internal Social Marketing Approach.” Journal of Marketing Management 28 (3-4): 469-493.

Smith, C. A., Organ, D. W., and Near, J. P. 1983. “Organizational Citizenship Behavior: Its Nature and Antecedents. Journal of Applied Psychology, 68(4), 653.

Soares, N., L. D. Pereira, J. Ferreira, P. Conceição, and P. Pereira da Silva. 2015. "Energy Efficiency of Higher Education Buildings: A Case Study." International Journal of Sustainability in Higher Education 16 (5) 669-691. doi: 10.1108/IJSHE-11-2013-0147 
Schultz, P., Oskamp, S., \& Mainieri, T. 1995. 'Who recycles and when? A review of personal and situational factors.' Journal of environmental psychology, 15(2), 105-121. http://dx.doi.org/10.1016/0272-4944(95)90019-5Starik, M., and Rands, G. P. 1995. Weaving an Integrated Web: Multilevel and Multisystem Perspectives of Ecologically Sustainable Organizations. Academy of Management Review 20(4): 908-935.

Steg, L., \& Vlek, C. 2009. "Encouraging pro-environmental behaviour: An integrative review and research agenda." Journal of Environmental Psychology, 29(3), 309-317. http://dx.doi.org/10.1016/j.jenvp.2008.10.004

Swain, J. A., M. J. Maloni, S. A. Napshin, and A. B. Henley. 2014. "Influences on Student Intention and Behavior Toward Environmental Sustainability." Journal of Business Ethics, 124 (3): 465-484.

Tonglet, M., P. S. Phillips, and A. D. Read. 2004. "Using the Theory of Planned Behaviour to Investigate the Determinants of Recycling Behaviour: A Case Study from Brixworth, UK.” Resources, Conservation and Recycling 41 (3): 191-214.

Tudor, T. L., S. W. Barr, A. W. Gilg. 2008. “A Novel Conceptual Framework for Examining Environmental Behaviour in Large Organisations: A Case Study of the Cornwall National Health Service (NHS) in the United Kingdom." Environment \& Behavior 40 (3): 426-450.

Unsworth, K.L., Dmitrieva, A., and Adriasola, E. 2013. "Changing behaviour: Increasing the effectiveness of workplace interventions in creating pro-environmental behaviour change.” Journal of Organizational Behavior, 34, 211-229. doi: 10.1002/job.1837

Vinning, J., and A. Ebreo. 2002. "Emerging Theoretical and methodological Perspectives on Conservation Behavior.” In: Bechtel, R.B and Churchman, A (2002) (eds) Handbook of Environmental Psychology, John Wiley and Sons, Inc: New York, 541-558. 
Young, W., Davis, M., McNeill, I.M., Malhotra, B., Russell, S., Unsworth, K and Clegg, C.W. 2015. “Changing Behaviour: Successful Environmental Programmes in the Workplace.” Business Strategy and the Environment, 24, 689-703. Doi: 10.1002/bse.1836 


\section{Figures}

Figure 1. Proposed theoretical model

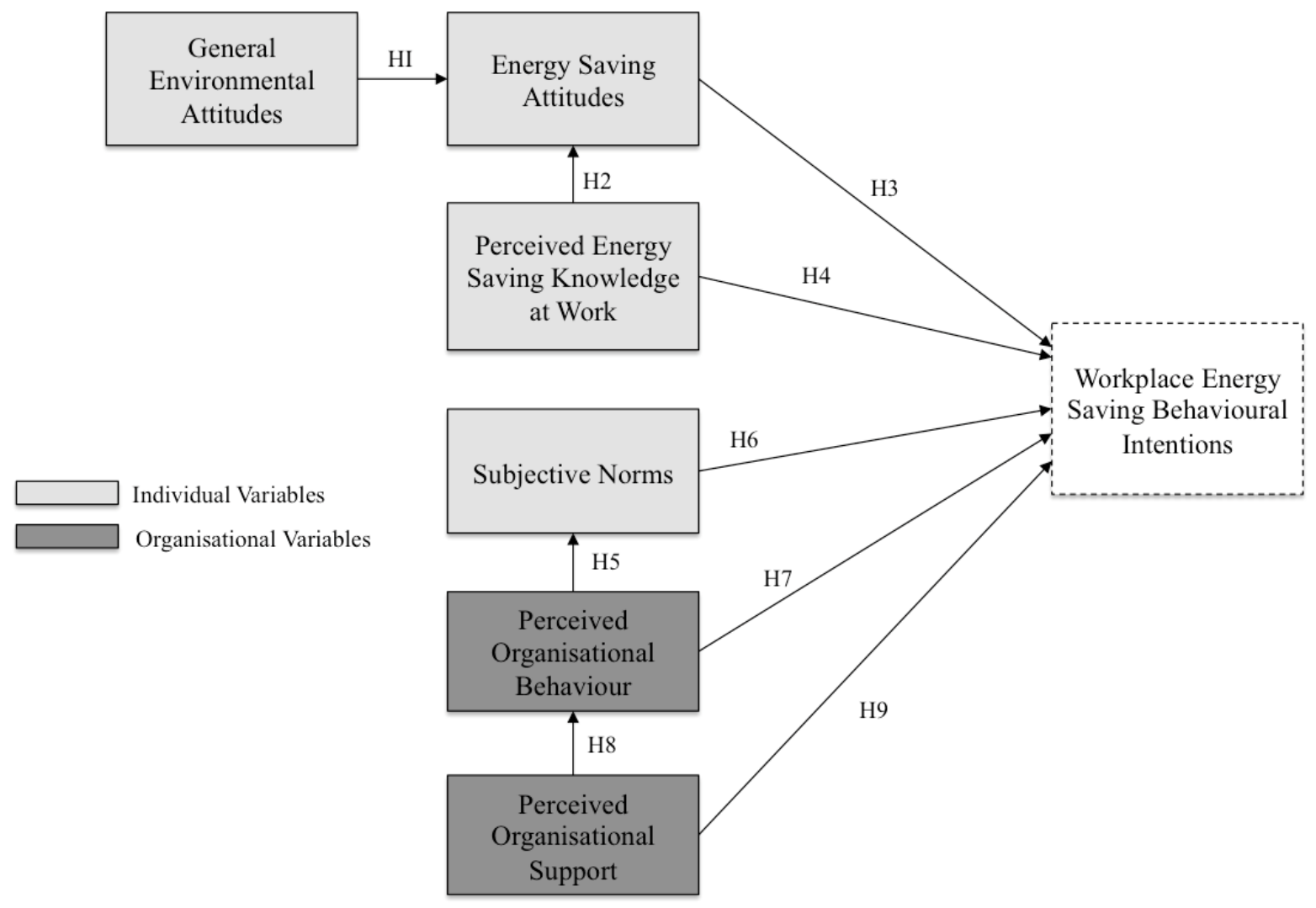




\section{Tables}

Table 1. Construct measures, exploratory factor analysis and cronbach's alpha

\begin{tabular}{|c|c|c|c|c|c|c|}
\hline \multicolumn{4}{|r|}{ EFA Loadings } & \multicolumn{3}{|c|}{ Cronbach's Alpha } \\
\hline Constructs & Scale Items & $\begin{array}{l}\text { Pre- } \\
\text { intervention } \\
\text { Sample }\end{array}$ & $\begin{array}{l}\text { Post- } \\
\text { intervention } \\
\text { Sample }\end{array}$ & $\begin{array}{l}\text { Pre- } \\
\text { intervention } \\
\text { Sample }\end{array}$ & $\begin{array}{l}\text { Post- } \\
\text { intervention } \\
\text { Sample }\end{array}$ & $\begin{array}{l}\text { Combined } \\
\text { Sample }\end{array}$ \\
\hline $\begin{array}{l}\text { Energy Saving } \\
\text { Attitudes }\end{array}$ & $\begin{array}{l}\text { 1. Conserving energy and natural resources is important to me. } \\
\text { 2. Conserving energy is not my problem. } \\
\text { 3. I have a responsibility to conserve energy and resources. }\end{array}$ & $\begin{array}{l}85 \\
.77 \\
.92\end{array}$ & $\begin{array}{l}.86 \\
.71 \\
.87\end{array}$ & $\mathrm{a}=.80$ & $\mathrm{a}=.75$ & $\mathrm{a}=.77$ \\
\hline $\begin{array}{l}\text { General Environmental } \\
\text { Attitudes }\end{array}$ & $\begin{array}{l}\text { 1. The effects of climate change are too far in the future to really worry me. } \\
\text { 2. It's not worth me doing things to help the environment if others don't do the } \\
\text { same. } \\
\text { 3. If things continue on their current course, we will soon experience a major } \\
\text { environmental disaster. } \\
\text { 4. It's only worth doing environmentally-friendly things if they save you money. } \\
\text { 5. It's not worth Britain trying to combat climate change because other countries } \\
\text { will just cancel out what we do. } \\
\text { 6. For the sake of the environment, car users should pay higher taxes. } \\
\text { 7. The environment is a low priority for me compared with a lot of other things in } \\
\text { 8. I would be prepared to pay more for environmentally-friendly products. }\end{array}$ & $\begin{array}{l}.74 \\
.72 \\
.65 \\
.69 \\
.77 \\
.60 \\
.75 \\
.69\end{array}$ & $\begin{array}{l}.63 \\
.71 \\
.56 \\
.72 \\
.79 \\
.58 \\
.72 \\
.63\end{array}$ & $\mathrm{a}=.86$ & $\mathrm{a}=.82$ & $\mathrm{a}=.84$ \\
\hline $\begin{array}{l}\text { Perceived } \\
\text { Organisational } \\
\text { Environmental } \\
\text { Behaviour }\end{array}$ & $\begin{array}{l}\text { 1. There is little information about recycling at my place of work. } \\
\text { 2. The University is 'green'. } \\
\text { 3. The University is as green as it could be. } \\
\text { 4. The University is committed to improving the environment. } \\
\text { 5. The University takes a pro-active approach to helping the environment. } \\
\text { 6. The University listens to feedback from staff regarding environmental issues. } \\
\text { 7. The University has coherent environmental attitudes. }\end{array}$ & $\begin{array}{l}.34 \\
.81 \\
.67 \\
.89 \\
.92 \\
.82 \\
.83\end{array}$ & $\begin{array}{l}.52 \\
.80 \\
.69 \\
.88 \\
.88 \\
.82 \\
.83\end{array}$ & $\mathrm{a}=.88$ & $\mathrm{a}=.89$ & $\mathrm{a}=.88$ \\
\hline $\begin{array}{l}\text { Perceived } \\
\text { Organisational Support }\end{array}$ & I receive support from the University to work in an environmentally friendly manner. & $\mathrm{n} / \mathrm{a}$ & $\mathrm{n} / \mathrm{a}$ & $\mathrm{n} / \mathrm{a}$ & $\mathrm{n} / \mathrm{a}$ & $\mathrm{n} / \mathrm{a}$ \\
\hline $\begin{array}{l}\text { Employee Subjective } \\
\text { Norms }\end{array}$ & There is too little concern for environmental issues among my colleagues. & $\mathrm{n} / \mathrm{a}$ & $\mathrm{n} / \mathrm{a}$ & $\mathrm{n} / \mathrm{a}$ & $\mathrm{n} / \mathrm{a}$ & $\mathrm{n} / \mathrm{a}$ \\
\hline
\end{tabular}




\begin{tabular}{|l|l|c|c|c|c|c|c|c|}
\hline $\begin{array}{l}\text { Perceived Energy } \\
\text { Saving Knowledge at } \\
\text { the Workplace }\end{array}$ & I know how to reduce energy use within my workplace. & $\mathrm{n} / \mathrm{a} / \mathrm{n} / \mathrm{n} / \mathrm{a}$ & & & & & & \\
\hline $\begin{array}{l}\text { Workplace Energy } \\
\text { Saving Behavioural } \\
\text { Intentions }\end{array}$ & I should help the University conserve energy. & $\mathrm{n} / \mathrm{a}$ & $\mathrm{n} / \mathrm{a}$ & $\mathrm{n} / \mathrm{a}$ & $\mathrm{n} / \mathrm{a}$ & $\mathrm{n} / \mathrm{a}$ & \\
\hline
\end{tabular}

Table 2. Descriptive statistics and correlations

\begin{tabular}{|c|c|c|c|c|c|c|c|c|c|c|}
\hline Variable Name & M (SD) & T-test: Differences & $\mathbf{n}$ & \multicolumn{7}{|c|}{ Correlations } \\
\hline \multicolumn{11}{|c|}{ Pre-intervention Sample $(n=164)$} \\
\hline Energy Saving Attitudes & $6.44(.69)$ & n.s. & 162 & 1 & & & & & & \\
\hline General Environmental Attitudes & $3.91(.61)$ & n.s. & 160 & $.66^{* *}$ & 1 & & & & & \\
\hline Perceived Organisational Environmental Behaviour & $4.68(.93)$ & n.s. & 144 & .13 & .05 & 1 & & & & \\
\hline Perceived Organisational Support & $3.67(1.44)$ & $\mathrm{t}(323)=-6.04 * *$ & 163 & -.07 & -.07 & $-.65^{* *}$ & 1 & & & \\
\hline Employee Subjective Norms & $4.03(1.51)$ & $t(318)=-2.52 *$ & 161 & -.09 & -.12 & $.42 * *$ & $-.24 * *$ & 1 & & \\
\hline Perceived Energy Saving Knowledge at the Workplace & $5.32(1.31)$ & $t(324)=-1.94 *$ & 162 & $.26^{* *}$ & $.22 * *$ & $.25^{* *}$ & $-.23 * *$ & -.03 & 1 & \\
\hline Workplace Energy Saving Behavioural Intentions & $6.48(.66)$ & n.s. & 163 & $.75^{* *}$ & $.55^{* *}$ & $.21^{*}$ & -.09 & -.09 & $.30^{* *}$ & 1 \\
\hline \multicolumn{11}{|c|}{ Post-intervention Sample $(n=164)$} \\
\hline Energy Saving Attitudes & $6.32(.77)$ & & 164 & 1 & & & & & & \\
\hline General Environmental Attitudes & $3.79(.61)$ & & 162 & $.52 * *$ & 1 & & & & & \\
\hline Perceived Organisational Environmental Behaviour & $4.79(.94)$ & & 152 & .08 & -.01 & 1 & & & & \\
\hline Perceived Organisational Support & $4.69(1.60)$ & & 162 & .10 & $.16^{*}$ & $.67 * *$ & 1 & & & \\
\hline Employee Subjective Norms & $4.46(1.52)$ & & 159 & .00 & -.05 & $.40 * *$ & $.25^{* *}$ & 1 & & \\
\hline Perceived Energy Saving Knowledge at the Workplace & $5.59(1.19)$ & & 164 & $.24 * *$ & .07 & $.37 * *$ & $.40^{* *}$ & .08 & 1 & \\
\hline Workplace Energy Saving Behavioural Intentions & $6.39(.81)$ & & 164 & $.71^{* *}$ & $.42 * *$ & .05 & .05 & -.04 & .10 & 1 \\
\hline
\end{tabular}

${ }^{* *} p \leq .01, * p \leq .05$, General environmental attitudes measured on 1 to 5 . All others measured on a 1-7. 
Table 3. Structural equation model results

\begin{tabular}{|c|c|c|c|c|c|c|c|c|}
\hline \multirow[b]{2}{*}{ Baseline Model Relationships } & \multicolumn{4}{|c|}{ Pre-intervention Sample } & \multicolumn{4}{|c|}{ Post-intervention Sample } \\
\hline & $\begin{array}{c}\text { Std. } \\
\text { Loadings }\end{array}$ & S.E. & $\begin{array}{c}\text { Z- } \\
\text { scores }\end{array}$ & $\begin{array}{l}\text { Hypothesis } \\
\text { Supported? }\end{array}$ & $\begin{array}{c}\text { Std. } \\
\text { Loadings }\end{array}$ & S.E. & $\begin{array}{c}\mathrm{z}- \\
\text { scores }\end{array}$ & $\begin{array}{l}\text { Hypothesis } \\
\text { Supported? }\end{array}$ \\
\hline H1: General environmentally friendly attitudes $\rightarrow$ Energy saving attitudes. & $.66^{* *}$ & .04 & 14.77 & Yes & $.52 * *$ & .06 & 8.92 & Yes \\
\hline H2: Perceived energy saving knowledge at the workplace $\rightarrow$ Energy saving attitudes & $.27 * *$ & .07 & 3.69 & Yes & $.23 * *$ & .08 & 3.10 & Yes \\
\hline H3: Energy saving attitudes $\rightarrow$ Workplace energy saving behavioural intentions & $.73^{* *}$ & .03 & 19.35 & Yes & $.73 * *$ & .04 & 18.03 & Yes \\
\hline $\begin{array}{l}\text { H4: Perceived energy saving knowledge at the workplace } \rightarrow \text { Workplace energy saving } \\
\text { behavioural intentions }\end{array}$ & .08 & .05 & 1.46 & No & -.09 & .06 & -1.45 & No \\
\hline H5: Subjective norms $\rightarrow$ Perceived organisational behaviour & $.45^{* *}$ & .06 & 6.58 & Yes & $.39 * *$ & .06 & 5.68 & Yes \\
\hline H6: Subjective norms $\rightarrow$ Workplace energy saving behavioural intentions & -.07 & .06 & -1.28 & No & -.06 & .06 & -1.02 & No \\
\hline $\begin{array}{l}\text { H7: Perceived organisational behaviour } \rightarrow \text { Workplace energy saving behavioural } \\
\text { intentions }\end{array}$ & $.20^{*}$ & .08 & 2.31 & Yes & .07 & .08 & .94 & No \\
\hline H8: Perceived organisational support $\rightarrow$ Perceived organisational behaviour & $-.64 * *$ & .05 & -13.06 & No & $.67^{* *}$ & .04 & 14.76 & Yes \\
\hline $\begin{array}{l}\text { H9: Perceived organisational support } \rightarrow \text { Workplace energy saving behavioural } \\
\text { intentions }\end{array}$ & .10 & .07 & 1.38 & No & -.02 & .08 & -.30 & No \\
\hline $\begin{array}{l}\text { Fit indices when SEM model is run separately for the pre and post-intervention } \\
\text { samples }\end{array}$ & \multicolumn{4}{|c|}{$\begin{array}{l}\chi_{(11)}^{2}=21.23, p=.03 ; \mathrm{CFI}=.97 ; \mathrm{TLI}=.95 ; \\
\mathrm{SRMR}=.07 ; \mathrm{R}^{2}=60 \%\end{array}$} & \multicolumn{4}{|c|}{$\begin{array}{l}\chi_{(11)}^{2}=37.77, \mathrm{p}=.00 ; \mathrm{CFI}=.91 ; \mathrm{TLI}=.84 \\
\mathrm{SRMR}=.09 ; \mathrm{R}^{2}=51.5 \%\end{array}$} \\
\hline
\end{tabular}

${ }^{* *} p \leq .01,{ }^{*} p \leq .05$, Multi-group SEM Overall: $\chi_{(22)}^{2}=59.00, \mathrm{p}=.00 ; \mathrm{CFI}=.94 ; \mathrm{TLI}=.90 ;$ SRMR $=.08$ 
Table 4. T-tests: Differences between pre and post-intervention samples within each job role.

\begin{tabular}{|c|c|c|c|c|c|}
\hline Constructs & & $\mathbf{N}$ & $\mathbf{M}$ & SD & \\
\hline \multicolumn{6}{|c|}{ Managers (Non-academic) } \\
\hline \multirow[t]{2}{*}{ Energy Saving Attitudes } & Pre & 81 & 6.55 & .62 & \multirow[t]{2}{*}{$t(154)=1.14$} \\
\hline & Post & 75 & 6.43 & .69 & \\
\hline \multirow[t]{2}{*}{ General Environmental Attitudes } & Pre & 79 & 3.91 & .65 & \multirow[t]{2}{*}{$t(155)=.656$} \\
\hline & Post & 75 & 3.85 & .60 & \\
\hline \multirow[t]{2}{*}{ Perceived Organisational Environmental Behaviour } & Pre & 72 & 4.67 & .89 & \multirow[t]{2}{*}{$t(155)=-.50$} \\
\hline & Post & 69 & 4.75 & .92 & \\
\hline \multirow[t]{2}{*}{ Perceived Organisational Support } & Pre & 82 & 3.69 & 1.37 & \multirow[t]{2}{*}{$\mathrm{t}(155)=-3.92 * *$} \\
\hline & Post & 75 & 4.62 & 1.60 & \\
\hline \multirow[t]{2}{*}{ Employee Subjective Norms } & Pre & 80 & 3.97 & 1.45 & \multirow[t]{2}{*}{$\mathrm{t}(152)=-2.40^{*}$} \\
\hline & Post & 74 & 4.54 & 1.46 & \\
\hline \multirow[t]{2}{*}{ Perceived Energy Saving Knowledge at the Workplace } & Pre & 82 & 5.42 & 1.23 & \multirow[t]{2}{*}{$t(155)=-1.22$} \\
\hline & Post & 75 & 5.66 & 1.21 & \\
\hline \multirow[t]{2}{*}{ Workplace Energy Saving Behavioural Intentions } & Pre & 82 & 6.54 & .66 & \multirow[t]{2}{*}{$\mathrm{t}(155)=1.24$} \\
\hline & Post & 75 & 6.38 & .95 & \\
\hline \multicolumn{6}{|c|}{ Academics } \\
\hline \multirow[t]{2}{*}{ Energy Saving Attitudes } & Pre & 13 & 6.35 & .85 & \multirow[t]{2}{*}{$\mathrm{t}(34)=.32$} \\
\hline & Post & 23 & 6.26 & .90 & \\
\hline \multirow[t]{2}{*}{ General Environmental Attitudes } & Pre & 13 & 4.15 & .59 & \multirow[t]{2}{*}{$t(33)=.68$} \\
\hline & Post & 22 & 3.97 & .82 & \\
\hline \multirow[t]{2}{*}{ Perceived Organisational Environmental Behaviour } & Pre & 12 & 3.96 & .79 & \multirow[t]{2}{*}{$\mathrm{t}(30)=-1.47$} \\
\hline & Post & 20 & 4.38 & .77 & \\
\hline \multirow[t]{2}{*}{ Perceived Organisational Support } & Pre & 12 & 4.58 & 1.56 & $\mathrm{t}(32)=.98$ \\
\hline & Post & 22 & 4.00 & 1.69 & \\
\hline Employee Subjective Norms & Pre & 13 & 4.07 & 1.60 & $\mathrm{t}(33)=-.77$ \\
\hline & Post & 22 & 4.54 & 1.79 & \\
\hline Perceived Energy Saving Knowledge at the Workplace & Pre & 12 & 5.08 & 1.31 & $t(33)=-.17$ \\
\hline & Post & 23 & 5.17 & 1.52 & \\
\hline Workplace Energy Saving Behavioural Intentions & Pre & 13 & 6.30 & .85 & $\mathrm{t}(34)=-.31$ \\
\hline & Post & 23 & 6.39 & .72 & \\
\hline Support & taff & & & & \\
\hline Energy Saving Attitudes & Pre & 64 & 6.31 & .74 & $\mathrm{t}(125)=.69$ \\
\hline & Post & 63 & 6.21 & .81 & \\
\hline General Environmental Attitudes & Pre & 64 & 3.86 & .56 & $\mathrm{t}(124)=2.02 *$ \\
\hline & Post & 62 & 3.66 & .53 & \\
\hline Perceived Organisational Environmental Behaviour & Pre & 57 & 4.84 & .96 & $\mathrm{t}(115)=-.72$ \\
\hline & Post & 60 & 4.97 & 1.0 & \\
\hline Perceived Organisational Support & Pre & 65 & 3.49 & 1.46 & $t(126)=-5.99 * *$ \\
\hline & Post & 63 & 5.04 & 1.46 & \\
\hline Employee Subjective Norms & Pre & 64 & 4.07 & 1.59 & $t(122)=-.96$ \\
\hline & Post & 60 & 4.35 & 1.53 & \\
\hline Perceived Energy Saving Knowledge at the Workplace & Pre & 64 & 5.21 & 1.43 & $\mathrm{t}(125)=-1.95^{*}$ \\
\hline & Post & 63 & 5.65 & 1.03 & \\
\hline Workplace Energy Saving Behavioural Intentions & Pre & 64 & 6.43 & .61 & $t(125)=.36$ \\
\hline & Post & 63 & 6.39 & .66 & \\
\hline
\end{tabular}

${ }^{* *} p \leq .01, * p \leq .05$, For job role groups: 'research staff only' and 'teaching staff only' differences between pre and post could not be compared as there was only one research staff in the post-intervention group and no teaching staff in the preintervention group. 
Table 5. T-tests: Differences between pre and post-intervention samples within each job duration group.

\begin{tabular}{|c|c|c|c|c|c|}
\hline Constructs & & $\mathbf{N}$ & $\mathbf{M}$ & SD & \\
\hline \multicolumn{6}{|c|}{ Less than 5 years } \\
\hline \multirow[t]{2}{*}{ Energy Saving Attitudes } & Pre & 48 & 6.49 & .64 & \multirow[t]{2}{*}{$\mathrm{t}(85)=1.24$} \\
\hline & Post & 39 & 6.31 & .67 & \\
\hline \multirow[t]{2}{*}{ General Environmental Attitudes } & Pre & 49 & 3.99 & .54 & \multirow[t]{2}{*}{$\mathrm{t}(184)=1.07$} \\
\hline & Post & 37 & 3.85 & .60 & \\
\hline \multirow[t]{2}{*}{ Perceived Organisational Environmental Behaviour } & Pre & 42 & 4.46 & .83 & \multirow[t]{2}{*}{$\mathrm{t}(75)=-2.49^{*}$} \\
\hline & Post & 35 & 4.91 & .70 & \\
\hline \multirow[t]{2}{*}{ Perceived Organisational Support } & Pre & 49 & 3.91 & 1.4 & \multirow[t]{2}{*}{$\mathrm{t}(86)=-2.69^{* *}$} \\
\hline & Post & 39 & 4.79 & 1.57 & \\
\hline \multirow[t]{2}{*}{ Employee Subjective Norms } & Pre & 48 & 3.85 & 1.52 & \multirow[t]{2}{*}{$\mathrm{t}(83)=-1.18$} \\
\hline & Post & 37 & 4.24 & 1.46 & \\
\hline \multirow[t]{2}{*}{ Perceived Energy Saving Knowledge at the Workplace } & Pre & 48 & 5.22 & 1.40 & \multirow[t]{2}{*}{$\mathrm{t}(85)=-.44$} \\
\hline & Post & 39 & 5.35 & 1.32 & \\
\hline \multirow[t]{2}{*}{ Workplace Energy Saving Behavioural Intentions } & Pre & 49 & 6.59 & .53 & \multirow[t]{2}{*}{$\mathrm{t}(86)=1.71$} \\
\hline & Post & 39 & 6.35 & .74 & \\
\hline \multicolumn{6}{|c|}{5 to 10 years } \\
\hline \multirow[t]{2}{*}{ Energy Saving Attitudes } & Pre & 57 & 6.46 & .64 & \multirow[t]{2}{*}{$\mathrm{t}(102)=.96$} \\
\hline & Post & 47 & 6.32 & .79 & \\
\hline \multirow[t]{2}{*}{ General Environmental Attitudes } & Pre & 56 & 3.79 & .56 & \multirow[t]{2}{*}{$\mathrm{t}(101)=.40$} \\
\hline & Post & 47 & 3.74 & .59 & \\
\hline \multirow[t]{2}{*}{ Perceived Organisational Environmental Behaviour } & Pre & 51 & 4.85 & .95 & \multirow[t]{2}{*}{$\mathrm{t}(92)=-.21$} \\
\hline & Post & 43 & 4.90 & 1.18 & \\
\hline \multirow[t]{2}{*}{ Perceived Organisational Support } & Pre & 58 & 3.36 & 1.28 & $\mathrm{t}(102)=-5.63 * *$ \\
\hline & Post & 46 & 5.00 & 1.68 & \\
\hline Employee Subjective Norms & Pre & 56 & 4.28 & 1.55 & $\mathrm{t}(100)=-.82$ \\
\hline & Post & 46 & 4.54 & 1.60 & \\
\hline Perceived Energy Saving Knowledge at the Workplace & Pre & 58 & 5.55 & 1.14 & $\mathrm{t}(103)=-.27$ \\
\hline & Post & 47 & 5.61 & 1.34 & \\
\hline Workplace Energy Saving Behavioural Intentions & Pre & 57 & 6.56 & .56 & $\mathrm{t}(102)=1.28$ \\
\hline & Post & 47 & 6.40 & .68 & \\
\hline More than 1 & 0 yea & & & & \\
\hline Energy Saving Attitudes & Pre & 57 & 6.38 & .79 & $t(130)=.11$ \\
\hline & Post & 75 & 6.36 & .79 & \\
\hline General Environmental Attitudes & Pre & 55 & 3.98 & .70 & $\mathrm{t}(128)=1.43$ \\
\hline & Post & 75 & 3.81 & .63 & \\
\hline Perceived Organisational Environmental Behaviour & Pre & 51 & 4.69 & .98 & $t(121)=-.01$ \\
\hline & Post & 72 & 4.69 & .89 & \\
\hline Perceived Organisational Support & Pre & 56 & 3.76 & 1.53 & $t(128)=-2.65^{* *}$ \\
\hline & Post & 74 & 4.48 & 1.52 & \\
\hline Employee Subjective Norms & Pre & 57 & 3.94 & 1.44 & $\mathrm{t}(128)=-2.33^{*}$ \\
\hline & Post & 73 & 4.56 & 1.52 & \\
\hline Perceived Energy Saving Knowledge at the Workplace & Pre & 56 & 5.17 & 1.38 & $\mathrm{t}(129)=-2.43^{*}$ \\
\hline & Post & 75 & 5.69 & 1.03 & \\
\hline Workplace Energy Saving Behavioural Intentions & Pre & 57 & 6.31 & .80 & $\mathrm{t}(130)=-.83$ \\
\hline & Post & 75 & 6.44 & .88 & \\
\hline
\end{tabular}

${ }^{* *} p \leq .01, * p \leq .05$ 